補緅誌, J Jpn Prosthodont Soc, 33 : 466 474, 1989.

原著論文

\title{
簡易型イオン導入器による象牙細管封鎖効果について
}

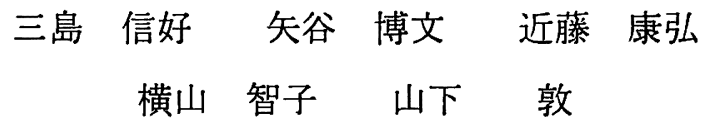

\section{Effect of Zinc Iontophoresis on Sealing of Dentinal Tubules by a New Handy Electolytic Applicator}

\author{
Nobuyoshi Mishima, Hirofumi Yatani, Yasuhiro Kondo, \\ Tomoko Yokoyama and Atsushi Yamashita
}

\begin{abstract}
The authors devised a new handy apparatus for iontophoresis in order to prevent pulp irritation caused by tooth reduction. This study was intended to observe the ability of the device.

$8 \%$ zinc chloride solution was iontophoresed in the dentin of extracted human and bovine teeth by the device. Then, the dye and microbial invasion tests were carried out to investigate how effectively it could seal the dentinal tubules.

The following conclusions were drawn :

1. By the zinc iontophoresis, the zinc briefly penetrated into the deep portion of the dentin.

2. The zinc iontophoresis by using the new device showed enough ability to decrease the coloring and bacterial invasion into the dentin, although all of the dentinal tubules were not sealed.

3. The tensile strengths of an adhesive luting resin 'Panavia EX' to the bovine dentin decreased significantly by the zinc iontophoresis. This phenomenon could be partly due to the lack of resin tag formation into the dentinal tubules.
\end{abstract}

Key words : iontophoresis, $\mathrm{ZnCl}_{2}$, pulp protection

\section{I. 緒 言}

生活歯に歯冠補緅を施す場合，歯剈道は多少なりとも障 害を受ける。したがって歯髄の消炎処置はもちろんのこ

岡山大学歯学部歯科補緅学第 1 講座 (主任 : 山下 敦教授)

Okayama University Dental School, Department of Fixed Prosthodontics (Chief : Prof. Atsushi Yamashita)

昭和 63 年 11 月 28 日受付
と支台歯形成から最終補緅物装着に至るまでの期間，外 来刺激を遮断し，歯䯚保護に努めなくてはならない。し かし，歯㵦保護に細心の注意を払ったにもかかわらず， 歯唱道が障害され，時として抜㵦を余儀なくされる事態に 陥ることがある，これまで歯哊損傷の原因として，歯牙 切削による機械的刺激あるいは温熱刺激, 合着材の化学 的刺激，辺縁漏洩に起因する細菌侵入，歯牙切削面の污 染等があげられている1 ${ }^{14)}$ ．このように歯冠補経や保存 修復に付随して起こる歯髄損稘の原因は，必ずしも現在 


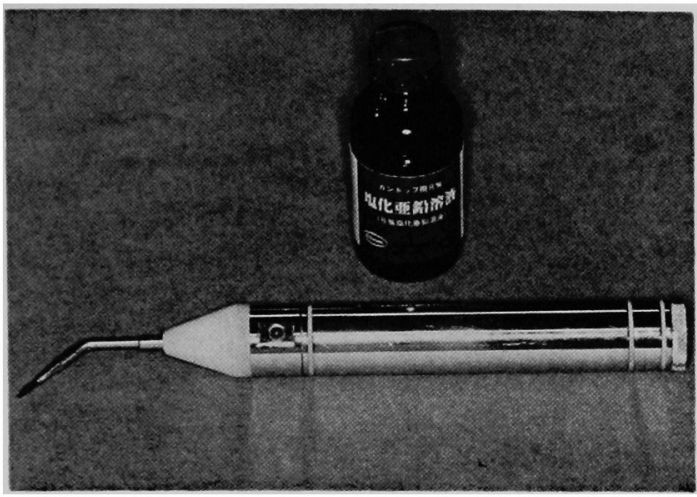

図 1 試作简易型イオン導入器と使用した $8 \%$ $\mathrm{ZnCl}_{2}$ 溶液

解明しつくされた訳ではないが，外部からの刺激が象牙 細管を通して歯㵦人伝えられ障害されることも一因であ ることは疑いの余地はない.

そこで著者らは, 従来, 象牙質知覚過敏症の知覚鈍麻 に用いられていたイオン導入法に着目し, 本法によれば 支台歯形成直後の形成面に開孔した象牙細管を積極的に 封鎖することができないかと考え, 電圧 $5.4 \mathrm{~V}$, 最大電 流 $50 \mathrm{~mA}$ の電流を用いる簡易型イオン導入器を試作し た (図 1).

この試作イオン導入器を用いて象牙細管封鎖効果を有 するとされる $8 \% \mathrm{ZnCl}_{2}$ 溶液を作用させ6)， ヒト正歯象 牙細管への亜鉛イオンの侵入度および細管への色素侵入 度を観察するとともに，牛歯象牙細管への細菌侵入度に ついて検討した．また，亜鉛イオン導入後の牛歯象牙質 に対する接着性レジンの接着強さについてもあわせて検 討を加えたので報告する.

\section{II. 実験材料および方法}

1. 試作イオン導入器による象牙細管の封鎖勃果の検 討

1) 実験齿

実験歯としてヒト臼歯および成牛前歯を使用した. 七 卜曰歯は, 拔歯直後に生理食塩水に浸漬して冷暗所に保 存し, 一週間以内に実験に供した. 牛歯は成牛を屠殺し た直後に抜歯し，歯娟組織を除去した後生理食塩水中に 漫湏し，一週間以内に実験に供した.

2) イオン導入用薬剤

本研究では, 冷暗所に保存した $8 \% \mathrm{ZnCl}_{2}$ 溶液（昭和 薬品化工社）を使用した6).

3）象牙細管への亜鉛イオン導入および侵入距離の測

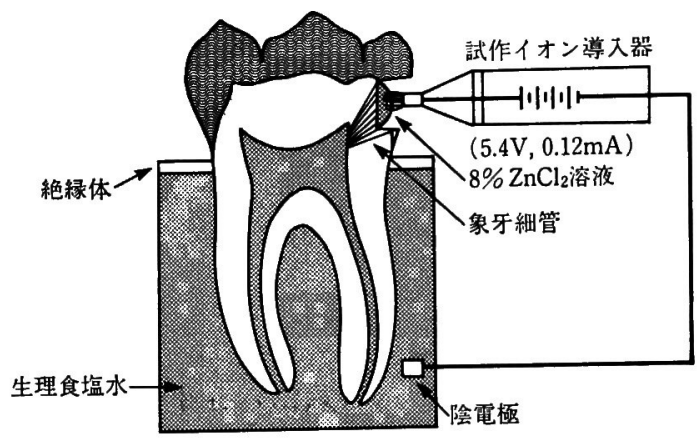

図 2 試作イオン導入器による帚鉛イオン導入

定

まず，ヒト毛歯の煩側および舌側軸面に $3 \times 3 \mathrm{~mm}$ の 面積で深さが約 $2 \mathrm{~mm}$ となり, 窝底が象牙質で終わる窩 洞を形成した. ついで $8 \% \mathrm{ZnCl}_{2}$ 溶液を含をせた試作イ オン導入器の筆を窝底に接触させ, 象牙細管を通して歯 䯚方向に $15 ， 30$ ならびに 60 秒間通電し，亜鉛イオンを 導入した (図 2). 通電せずに同時間薬剤狳布のみを行っ たものを対照とした. イオン導入後あるいは塗布終了後 䆟洞を水洗し，窩洞を含んだ煩舌側方向に実験歯を切断 した後, $0.2 \%$ ジチジンアンモニウム溶液中に浸漬し， 象牙細管内の亜鉛を検出した. 亜鉛の侵入距離は, ニコ ン F 3 (日本光学社) を用いて歯牙断面を撮影し, これ を 7.3 倍に拡大したカラープリント上で 10 名がノギス を用いて象牙細管に侵入した亜鉛の窝底からの距離を $1 / 10 \mathrm{~mm}$ まで計測することにより求め, その平均值を 代表値とした。

4）象牙細管への色素侵入距離の測定

3）と同様に形成した窝洞に，試作イオン導入器を 用 いて $8 \% \mathrm{ZnCl}_{2}$ 溶液を $15,30,60$ ，ならびに 90 秒間作 用させた後，䆟洞以外の歯質表面にネイルエナメル（マ ックスファクター社）を珡布し， $0.2 \%$ 塩基性フクシン 水溶液中に 24 時間浸漬して実験資料とした. 色素の侵 入距離は 3）と同様の方法で測定した.

5）象牙細管への細菌侵入の抑制効果の検討

図 3 左に示すよ $5 に$, 牛歯象牙質片に直径 $3 \mathrm{~mm}$ の円 形窝洞を窩底象牙質の厚さが $1 \mathrm{~mm}$ となるように形成 し，この窝洞を内部に包括する形で内径 $6 \mathrm{~mm}$, 高さ 90 $\mathrm{mm}$ のガラス管をエポキシ系接着材を用いて接着し，ま ずこれを 24 時間室温で硬化させた. 歯牙処理は, 試作 イオン導入器を用いて形成窩洞内に $8 \% \mathrm{ZnCl}_{2}$ 溶液を 30 秒間あるいは 60 秒間作用させた場合と，無処理の場 合の 3 種とした. つぎに, BHI 培地 (DIFCO 社製) を $5 \mathrm{cc}$ 入れた試験管内に前述した資料を図 3 右に示す 


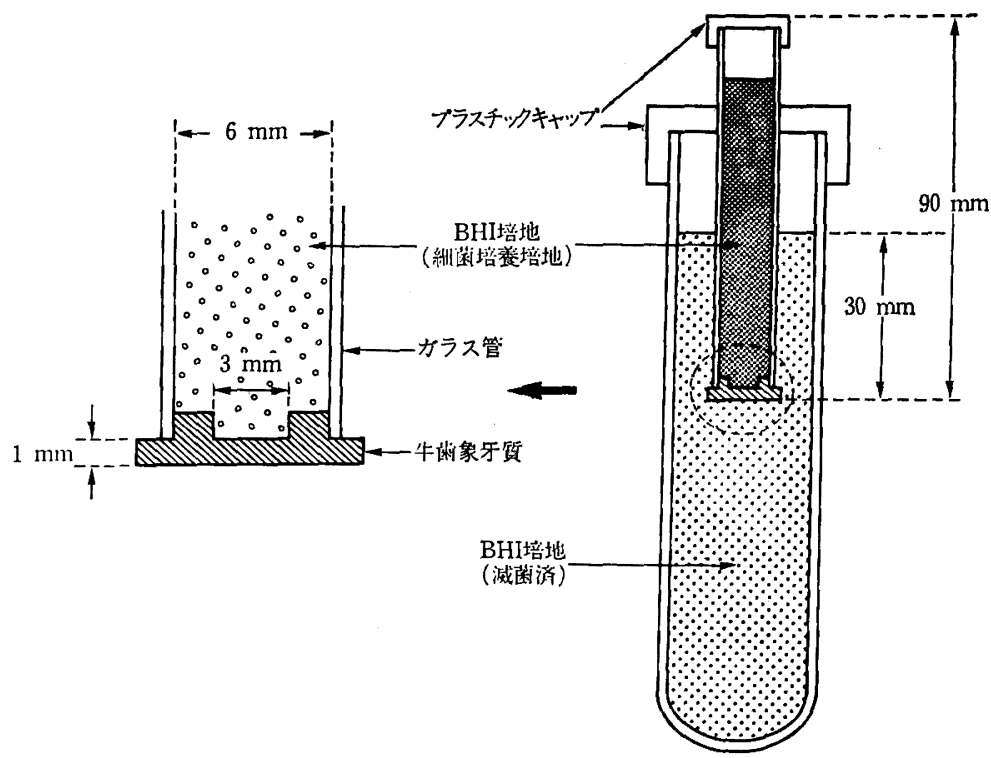

図 3 細菌通過実験模式図

深さまで浸漬し、プラスチックキャップとガラス管の間 隙をエポキシ系接着材で封鎖した。 なお実験に先立ち, 実験器材および牛歯はエチレンオキサイドガスで 24 時 間滅菌し，培地はオートクレーブにて $120^{\circ} \mathrm{C} て ゙ ~ 15$ 分間 の滅菌処理を施した。

被験菌は，象牙細管の通過が可能な大きさと形状であ ることを考虑して，球菌である St. mutans と桿菌であ るE. coli の 2 種類の菌を選択した. St. mutans は直径 $0.5 \sim 0.8 \mu \mathrm{m}, E$. coli は幅 $1.1 \sim 1.5 \mu \mathrm{m}$ 長さ $2.0 \sim 6.0$ $\mu \mathrm{m}$ で, 今回使用した牛歯の象牙細管の断面は直径 3.0 $\sim 5.0 \mu \mathrm{m}$ の円形であった. 2 種の菌を $10 \mathrm{~m} l$ の BHI 培 地に各々 1 エーゼずつ釣菌し, $37^{\circ} \mathrm{C}$ 恒温槽内で 24 時間 培羔したものを 1,000 倍希䣋し，混濁度計（日立社製 Model 100-10）による計測で混澴度 0.5 に達するまで培 養した. 培養した菌 $1 \mathrm{cc}$ を図 3 右の上部ガラス管に注 入し，上部を滅菌したゴム管とクリップで封鎖した後, $37^{\circ} \mathrm{C}$ 恒温槽内で培養し, 細菌が象牙細管を通過して下 部試験管内の BHI 培地で増殖する経過を混濁度計を用 いて経時的に観察した. なお， 2 種の細菌の growth curve むあわせて観察した.

\section{2. 覀鉛イオン導入が象牙質面の接着強さに及ぼす影 響}

牛歯唇側のエナメル質を削除して象牙質を露出させ， 耐水エメリーペーパーで聿600 まで平滑研磨し被着面 とした.この被着面に試作イオン導入器を用いて $8 \%$

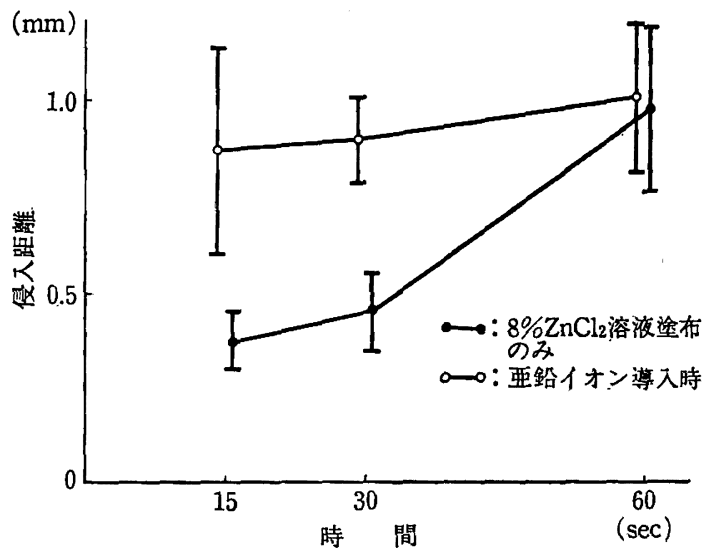

図 4 要鉛の侵入距離の释時的変化

$\mathrm{ZnCl}_{2}$ 溶液を 30 秒間作用させ, 水洗乾燥 後, $40 \%$ リ ン酸で 60 秒間 エッチングを行った. ついで平均粒径 $50 \mu \mathrm{m}$ の $\mathrm{Al}_{2} \mathrm{O}_{3}$ で 5 秒間サンドブラスト処理した直 径 $7 \mathrm{~mm}$ のステンレス SUS 304 円柱棒をパナビア EX （クラレ社）を用いて牛歯被着面に自重で接着した，装 着の完了した資料を $37^{\circ} \mathrm{C}$ 恒温槽中に 24 時間放置した 後, 島津製作所製オートグラフ DCS-2000 を用いてク

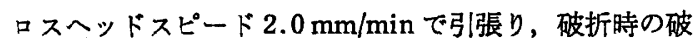
壊応力を接着強さとして求めた。 また，エッチング 後 SUS 304 円柱棒を接着した資料を $2 \mathrm{~N}$ の $\mathrm{HCl}$ で脱灰し， 象牙細管内に形成されたレジンタグを観察した。 


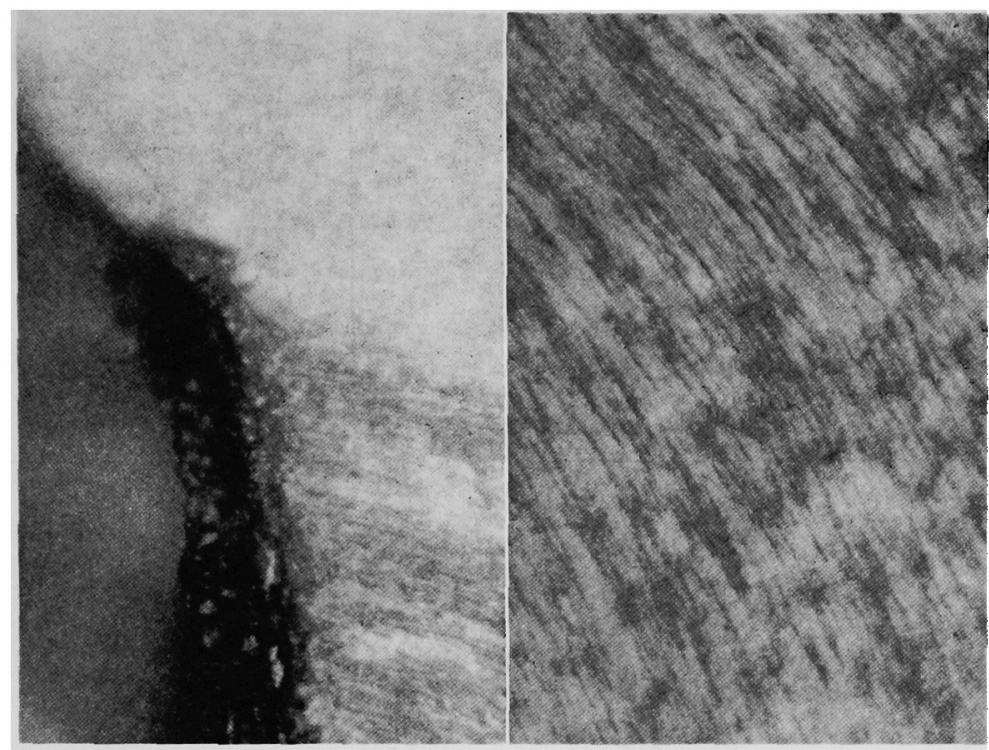

a . 窩洞直下

b. 象牙質中層部

図 5 象牙䋑管への亜鉛の侵入

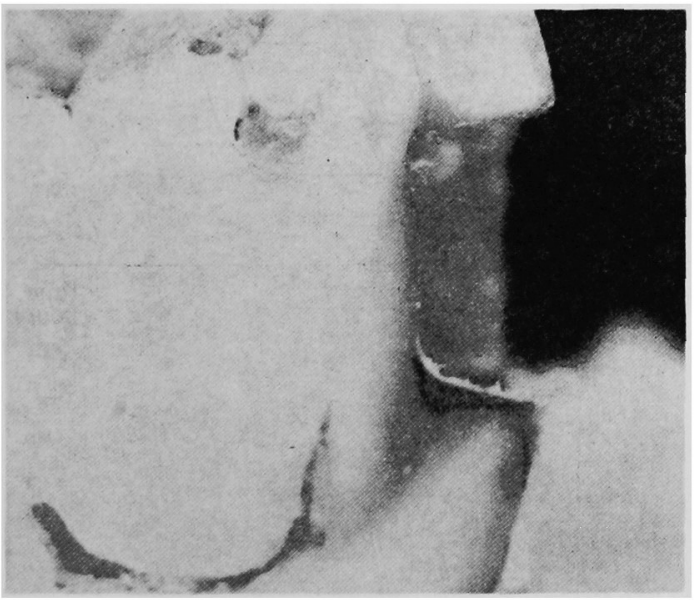

图 6 象牙細管人の色素の侵入状態

III. 結 果

\section{1. 象牙細管における爰鉛イオンの検出}

図 4 に亜鉛の侵入距離を示す，試作イオン導入器を使 用した場合, 作用時間が 15 秒では敍布のみの約 2.3 倍, 30 秒間では塗布のみの約 2 倍の距離まで重鉛が侵入し たが, 60 秒間ではほぼ同じ侵入距離となった。図 5 は, 試作イオン導入器を用いて $8 \% \mathrm{ZnCl}_{2}$ 溶液を 15 秒間作 用させた歯牙断面を実体顕微鏡イグザメット（ユニオン
表 1 色溸侵入試験の結果

\begin{tabular}{|c|c|c|c|}
\hline & - & + & H \\
\hline Control & 0 & 1 & 13 \\
\hline $\begin{array}{l}\mathrm{ZnCl}_{2} \\
15 \mathrm{sec}\end{array}$ & 0 & 2 & 14 \\
\hline $\begin{array}{l}\mathrm{ZnCl}_{2} \\
30 \mathrm{sec}\end{array}$ & 4 & 2 & 10 \\
\hline $\begin{array}{l}\mathrm{ZnCl}_{2} \\
60 \mathrm{sec}\end{array}$ & 7 & 2 & 7 \\
\hline $\begin{array}{l}\mathrm{ZnCl}_{2} \\
90 \mathrm{sec}\end{array}$ & 6 & 3 & 7 \\
\hline $\begin{array}{l}\mathrm{ZnCl}_{2} \\
30 \mathrm{sec}\end{array} \times 3$ & 6 & 4 & 6 \\
\hline
\end{tabular}

社）により桩大撮影した亜鉛の染色状態を示している.

\section{2. 象牙細管への色素侵入}

図 6 に色素の侵入状態，表 1 に色素侵入の判定結果を 示寸.

塗布のみの場合と 15 秒間イオン導入を行った場合は, ともに歯髄まで著しい色素の侵入が観察された. 30 秒間 と 60 秒間イオン導入を行った場合は，色素が歯髄まで 侵入した窩洞は減少し，色素が侵入しない窩洞が増加し た.さらに 90 秒間イオン導入を行った場合と 30 秒間ず つ 3 回行った場合も検索したが, 60 秒間の場合と差は認 

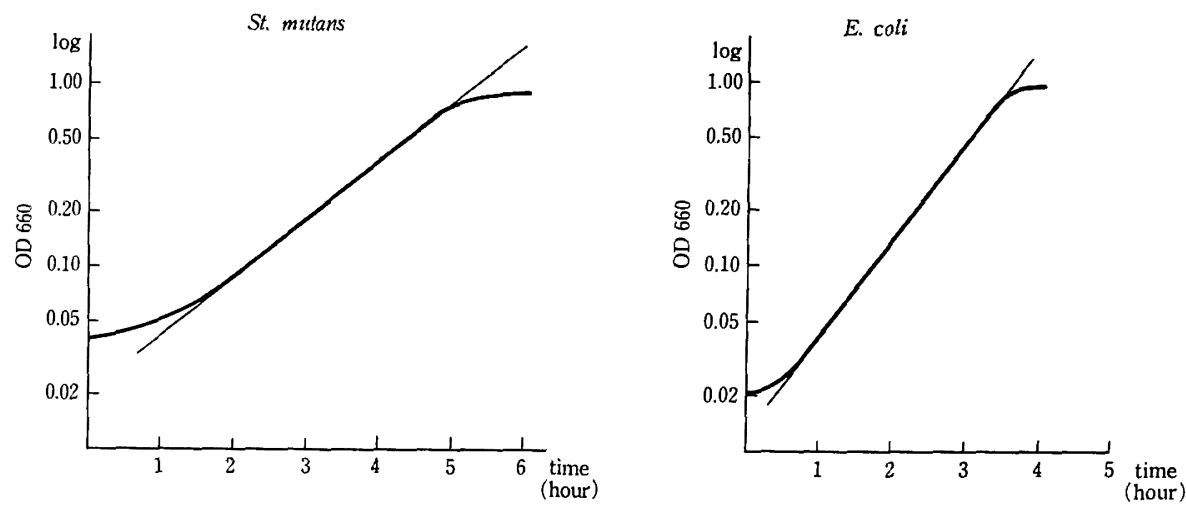

generation time
St. mutans : $60 \mathrm{~min}$
$E$. coli $: 33 \mathrm{~min}$

図 72 種の細菌の growth curve と generation time

められなかった。

\section{3. 象牙細管への細菌侵入}

図 7 に $37^{\circ} \mathrm{C}$ 恒温槽内の $\mathrm{BHI}$ 培地で培養した場合の 2 種の菌の growth curve と generation time を示す. Generation time は, St. mutans が 60 秒, E. coli が 33 秒であった. Growth curve は, BHI 培地で増殖する細 菌の数を混濁度計を用いて計測した数值の経時的変化を 表し, この直線部分より細菌の増殖する速度, すなわち generation time が得られる.

図 8 は，象牙細管を通過し下部試験管で增殖した細菌 の混濁度を一定時間ごとに計測して得られた growth curve で, generation time に従って接線を引き, 細菌 が最初に象牙細管を通過した時間を推察した.

St. mutans は，亜鉛イオン導入を 30 秒間执よび 60 秒間行った場合，対照と比較して細菌の growth curve が右方に移動しており，細菌が象牙細管を通過するのに 要する時間が長くなっていることが確認された。，一方， E. coli では, 亜鉛イオン導入を行うと象牙細管を通過 して下部試験管内で増殖した試料が減少した. 60 時間後 までに下部試験管内で増殖のみられなかった試料は，歯 面処理しなかった場合 $29 \%$, 試作イオン導入器で 30 秒 間亜鉛イオン導入を行った場合 $58 \% ， 60$ 秒間行った場 合 $60 \%$ であった。

\section{4. 亜鉛イオン導入が接着強さに及ぼす影響}

図 9 は象牙質に形成されたレジンタグの SEM 像を示 す、イオン導入を行わなかった場合は著明にレジンタグ
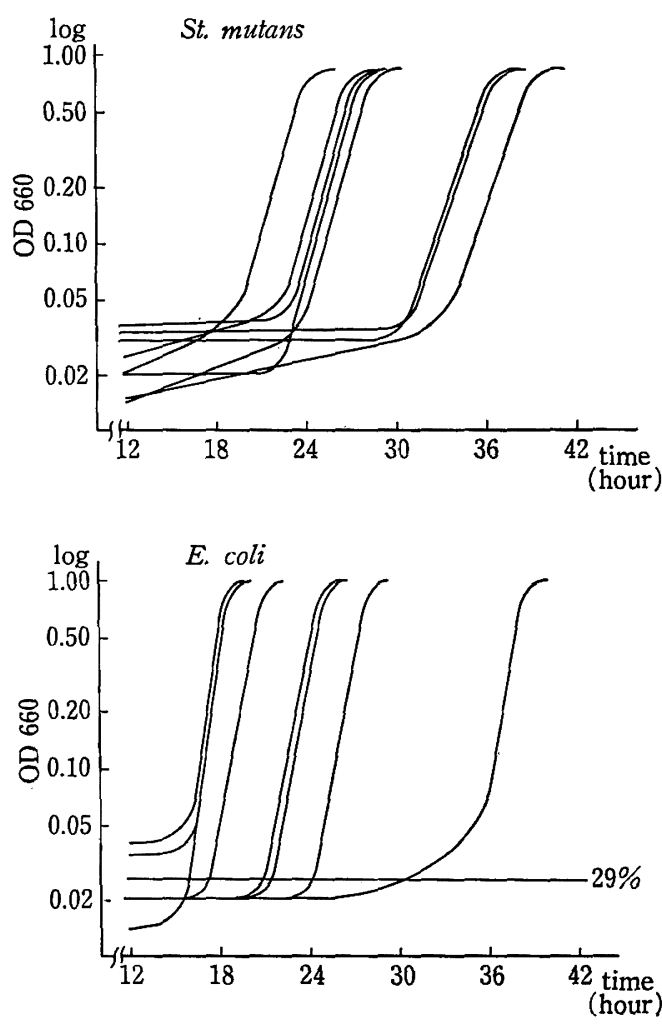

因 8-a 細菌の通過状態 (リン酸エッチングのみ)

の形成が認められるが, $8 \% \mathrm{ZnCl}_{2}$ 溶液を試作イオン導 入器を使用して 30 秒間作用させた場合では,レジンタグ の形成はほとんど認められなかった。図 10 に引張り接 着強さ試験の結果を示す.エッチングのみの場合, 平均 

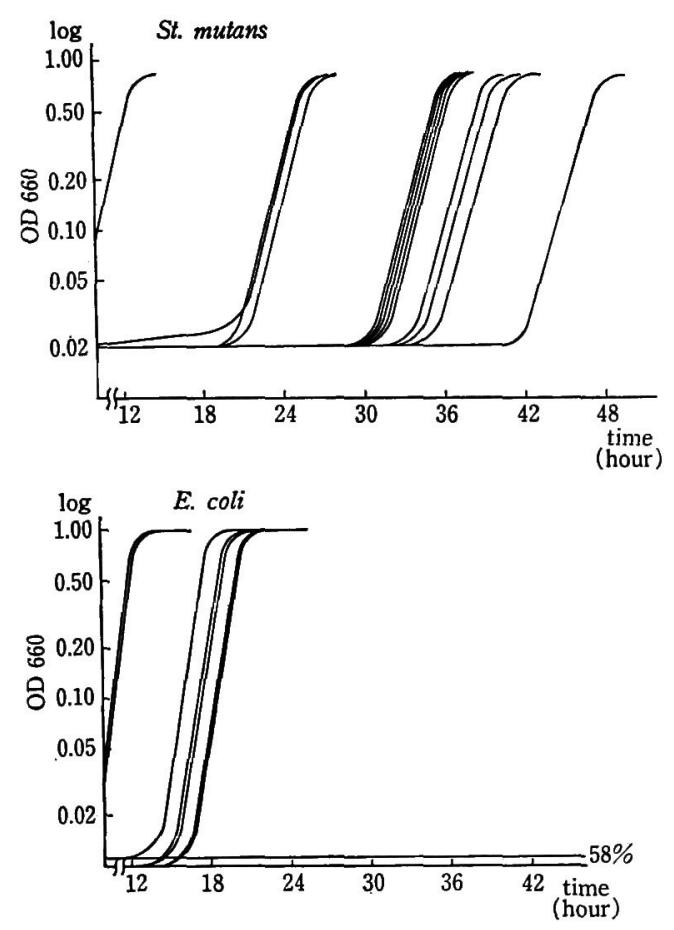

図 8-b 細菌の通過状態（垔鉛イオン導入 30 秒）
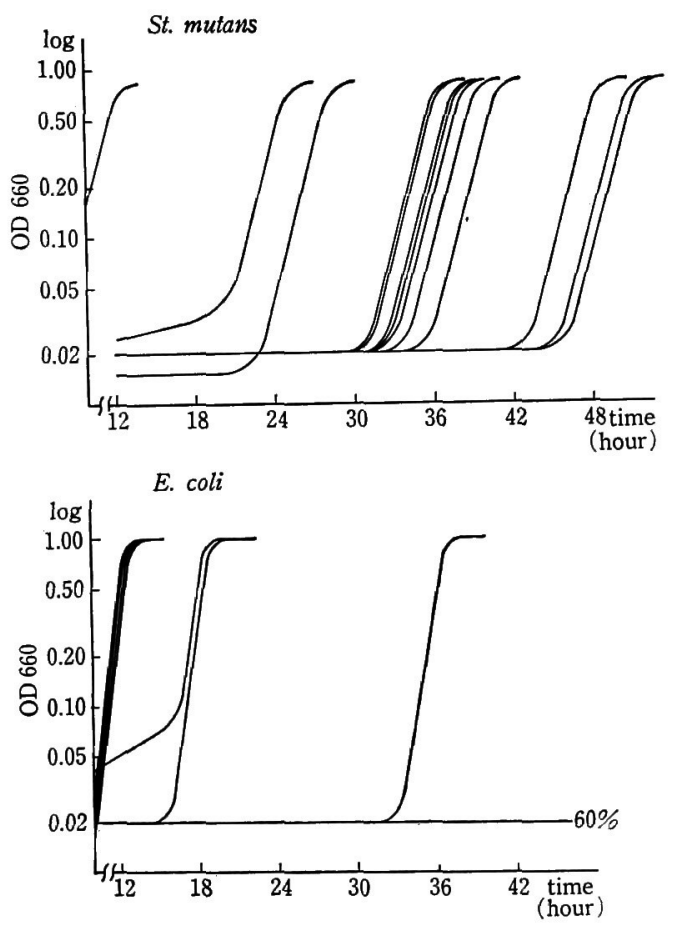

図 8-c 細菌の通過状態（価鉛イオン導入 60 秒）

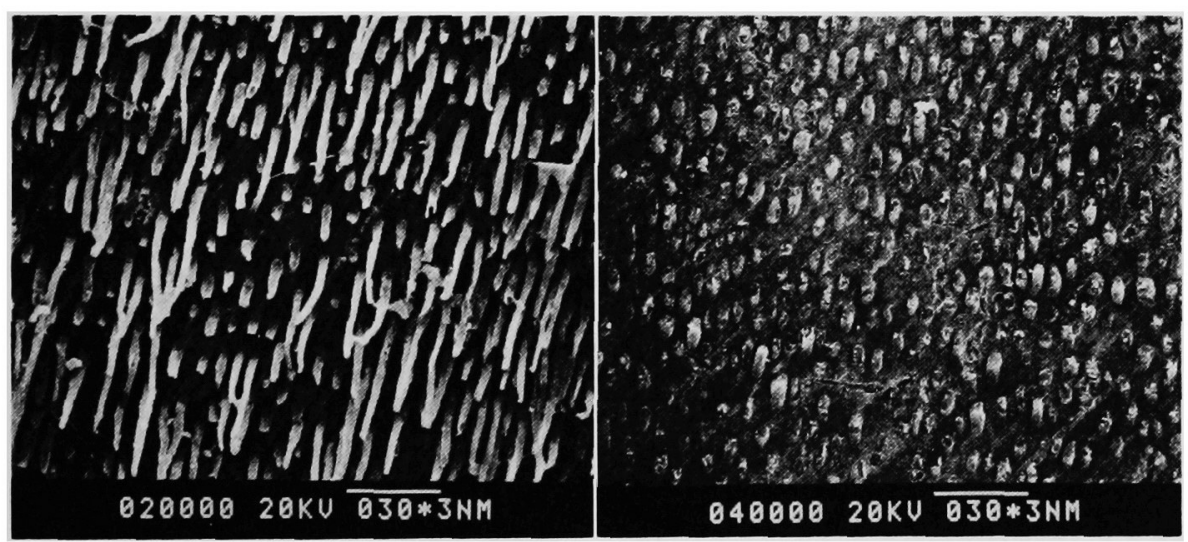

$\mathrm{a}$ ：リン酸エッチングのみ $(60$ 秒 $)$

$\mathrm{b}$ ：リン酸エッチング(60 秒)後, 亜鉛イオン導入 (30秒)

図 9 牛歯象牙質に形成されたレジンタグ

$25.6 \mathrm{kgf} / \mathrm{cm}^{2}$, 亜鉛イオン導入後にエッチングを行った 場合, 平均 $12.7 \mathrm{kgf} / \mathrm{cm}^{2}$ であり,レジンタグの減少に 対応して引張り強さも減少した.

\section{IV. 考察}

保存補緅修復時に時として歯䯚損傷を引き起こすこと
は古くから知られている.この歯髄損傷が起こる原因に ついては現在でも議論の余地を多く残しているが，大別 すると 3 つの原因説があるようである. すなわち，1つ は窝洞形成時の刺激であり，1つは修復材料による刺 激，さらにもう1つは辺縁漏洩による刺激である

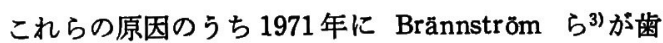
鹃刺激を生じた修復物の窩底に多くの細菌を発見したの 


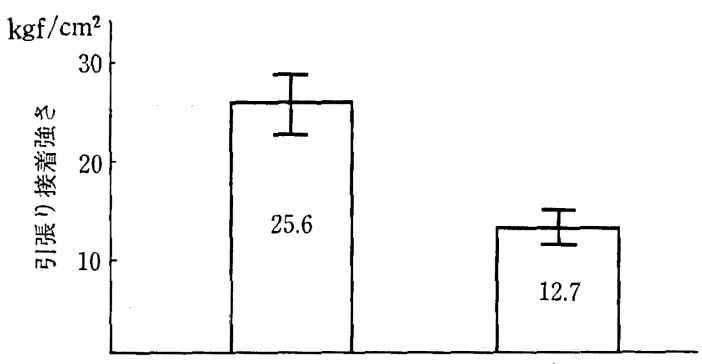

a

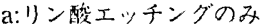

b:リン酸エッチング後严鉛イオン導入(30秒)

図 10 象牙質に対する引張り接着強さ

を機に，辺縁漏洩により侵入した細菌の毒素により歯髄 損傷が起こるとする説が重要視されるに至った．最近に なって，この歯髄損傷の原因の寸べてが細菌によるもの だとする説には反論が出されておりら)，結論を得るには まだ時間が必要である。しかし，歯髄刺激の原因がいず れにあるにせよ，刺激は象牙細管を通じて歯髄に達する ことには議論の余地がない，したがって象牙細管の封鎖 を図ることによって，歯髄損傷を防ぐことは修復の基本 原則であると考える.

この細管封鎖は，硧窩に対する保存修復処置において はカルボキシレートセメントやアイオノマーセメント等 による裹層といら形で行われている。しかし，これらの 材料と象牙質との接着力はきわめて弱いため7)，コンポ ジットレジンの重合収縮により裏層材が窩底象牙質から 浮き上がって間隙ができる欠点が指摘されている5)。 こ れに対し，近年象牙質に高い親和性をもつ接着材やボン ディング材の開発が進められているが，これとても象牙 質との接着力はエナメル質に対するそれと比較していま だ十分でなく，特に耐久性には問題がある8).

したがって現時点においては支台歯形成した生活歯の 歯髄を確実に保護する方法として，物理的に象牙細管の 封鎖を図るイオン導入法は優れた方法の 1 つであると考 える.

\section{1. 試作簡易型イオン導入器について}

イオン導入法はイオン化した薬剤中の荷電粓子を電場 の力を借りて積極的に拡散移動させる術式で，基本的原 理は電気泳動法と同じである. 本法は歯科においては感 染根管治療や象牙質知覚過敏の治療に広く利用されてお り, 従来より種々のイオン導入器が市販されている. 本 研究で試作した試作簡易型イオン導入器は従来の機器に 比へて小型で，操作も簡単である．本器の使用にあたっ
33 巻 2 号 (1989)

てはまず筆状の関電導子に薬液を十分に浸して患部に接 触させ, 術者が指で患者の煩粘膜に触れると両者の間に 回路が形成され，ランプが点灯してイオン導入が開始さ れる. 本器は電源として KANTOP-ACE（昭和薬品化 工製)を使用しており，この電池の向きを変えるだけで 陽イオン導入にも陰イオン導入にも利用できるという特 徵をもつ.

\section{2. イオン導入による亜鉛イオンの象牙質への浸透状 態について}

イオン導入に利用される主な薬剤には $2 \%$ フッ化ナト リウム溶液と $8 \%$ 塩化亜鉛溶液がある．特に前者による フッ素イオン導入法については, 多くの研究者により臨 佅成績が報告されて㧍り 9 11)，歯科においては最も一般 的な方法であるが，本研究においては染色法によりイオ ンの象牙質内への浸透状態を観察するため，金属イオン である亜鉛イオン導入を選択した。

井上6) は鍍金法により覀鉛の象牙質への浸透状態を観 察し，イオン導入を行うと亜鉛が細管にそってほとんど 歯髄に達するまで侵入するが，塩化亜鉛溶液を塗布した だけでは愛鉛はほとんど象牙質内へ浸透しなかったと報 告した。 また，藤正 ${ }^{12)}$ は亜鉛イオン導入した歯の象牙質 をX線マイクロアナライザーにより分析した結果，亜鉛 はほとんど象牙細管内で検出され，その浸透深度は導入 時間に依存することを示した。 さらに象牙細管の閉塞に よると思われる亜鉛イオン導入後の象牙質の電気抵抗値 の増大を明らかにしたが，塗布のみでは抵抗值にほとん ど変化を認めず，亜鉛はほとんど浸透しないことを示唆 した.

このように亜鉛イオンは塩化亜鉛溶液を塗布しただけ では象牙細管にはほとんど浸透せず，イオン導入を行っ て初めて象牙細管内深くまで浸透するものと思われる.

本研究に掠いても通電時間 15 秒と 30 秒においては, 亜鉛イオンの浸透状態は同時間溶液を塗布した場合と比 較して有意に大きい侵入距離を示した.しかし，塗布の みの場合でも 60 秒経過後にはイオン導入を行った場 合 とほぼ同様の侵入距離を示した。この理由については必 ずし明らかではないが, 本研究においては実験歯を切 断してから亜鉛を染色したため，切断時に亜鉛が歯髄方 向へ移動した可能性が考えられる，このことはイオン導 入時に亜鉛は早期に深くまで侵入しており，その侵入距 離は導入時間にほとんど影響を受けていないことからも 推察できる.

また，鍍金法による観察は単に金属の存在の有無を検 
出するもので，象牙細管の封鎖あるいは閉塞の程度に関 する情報は得られない. そこで, 試作簡易型イオン導入 器を用いた亜鉛イオン導入による象牙細管の封鎖効果を より正確に検討するため, 色素侵入試験および細菌通過 試験を行った.

\section{3. 垔鉛イオン導入による象牙細管の封鎖効果につい $\tau$}

亜鉛イオン導入によるヒト象牙兵に対する色素侵入の 抑制効果は，通電時間の増加とともに向上した. しか し, 通電時間が 60 秒間と 90 秒間ではその抑制効果にほ とんど差が認められなかった．実験で使用した試作簡易 型イオン導入器のように定電流を通電する方法では, 通 電時に分極が起こって電流值が低下する現象が知られて いる. 電流值が低下すれば当然イオンの象牙質内一の輸 送量は減少する. そこで，色素侵入の抑制効果の頭打ち がこの分極現象によるものかどうかを確認するため，通 電時間を 30 秒ずっ 3 回にわけてイオン導入を行い, 色 素侵入の抑制効果を観察したが，やはり60秒間および 90 秒間の通電における抑制効果と変化は認められなか った. このことは約 60 秒間の通電により, 象牙細管内 にすでに飽和に近い量の亜鉛イオンが取込まれることを 示唆している.

その一方で, イオン導入後も歯髄まで色素が侵入した 実験歯が約半数に認められたが, この結果がそのままイ オン導入による歯髄保護の效率の悪さを物語るものでは ない. というのは, 亜鉛イオンにより象牙細管が狭窄し ても閉錤されなければ色素は侵入するが，生物学的には 狭窄するだけで象牙細管内の組織液の移動が抑制され， 歯髄障害が起こる可能性は減少すると考えられるからで ある.

亜鉛イオン導入による象牙細管の狭窄は，大きさの異 なる 2 種の細菌を用いた細菌通過実験により確認するこ とができた. St. mutans よりも大きいE. coli は 60 秒 間の亜鉛イオン導入を行った実験歯の $60 \%$ で全く細管 を通過しなかった. これに対し, St. mutans は, 通過時 間は延長するものの細管を通過しない実験歯の数は対照 と差が認められなかった.このことは窩洞内に開口した 象牙細管は，亜鉛イオン導入により完全封鎖されること がほとんどないことを示しており，イオン導入された象 牙細管中の金属の分布は一様ではなく，まったく金属が 検出されない細管も認められたとする藤正の報告 ${ }^{12)}$ とも 一致する. いずれにせよ，イオン導入によって象牙細管 に浸透した亜鉛イオンは歯質蛋白を凝固させるととも
に，歯質無機質中のカルシウムと㯰換してリン酸亜鉛を 形成し，象牙細管を填塞するものと思われる ${ }^{6,13)}$. した がって形成歯に対する試作簡易型イオン導入器による亜 鉛イオン導入は有効な歯髄保護対策の 1 つであると考え られる.

\section{4. 垔鉛イオンの迸入が接着強さに及ぼす影響}

亜鉛イオンを導入した牛歯象牙質に対するパナビア $\mathrm{EX}$ の接着強さは，イオン導入を施さない場合と比較し て約半分に減少した，接着試験片を脱灰して SEM によ り観察したところ，亜鉛イオンを導入した牛歯象牙質に おいては，レジンタグがほとんど形成されておらず，接 着面積が減少して接着強さが低下したと説明できる．山 賀 ${ }^{13)}$ は，亜鉛により歯質中の無機質の耐酸性が向上する と述へてたり，亜鉛イオン導入を行った象牙質をリン酸 によりエッチングしても十分に脱灰が進行せず，レジン が象牙細管に侵入しないものと考えられる. イオン導入 により象牙質の接着強さが減少することは，イオン導入 による歯髄保護の臨床上の 1 つの欠点であろう。

\section{V. 結 論}

ヒト臼歯象牙質および牛歯象牙質を用いて，試作簡易 型イオン導入器による亜鉛イオンの象牙細管への導入 度, 象牙細管の封鎖効果, さらに亜鉛イオンが接着性レ ジンの象牙質に対する接着強さに及ぼす影響について検 索し, 以下の結論を得た.

1. 試作イオン導入器により, 短時間のうちに象牙細 管深部にまで亜鉛イオンを導入することが可能であっ た.

2. 亜鉛イオンによる象牙細管の封鎖は完全には行わ れなかったが，色素侵入および細菌侵入を抑制すること が可能であった.

3. 亜鉛イオン導入により，象牙質の耐酸性が向上 し，エッチングによる歯髄損傷を減ずることが可能であ ると推察されたが, パナピア EX との接着強度は低下し た.

4. 以上より，生活歯に歯冠補緅を施す場合，支台歯 形成直後に形成面に対して亜鉛イオン導入を行うことに より，支台歯形成や装着材による損傷を有効に防ぎ得る ことが示唆された.

稿を終るにあたり，細菌通過実験について多くのご助言を頂 きました本学歯学部口腔細菌学教室の加藤慶二郎教授, 福井和 
博助教授，苔口 進助手に深甚なる感謝の意を表します. 本研究の要旨は第 75 回日本補緅歯科学会学街大会にて発表し た.

\section{文献}

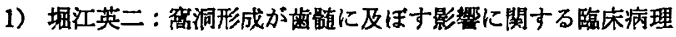
学的研究, 日歯保誌, $4: 1 \sim 55,1961$.

2) Zander, H.A. : Pulp response to restorative materials, J Amer Dent Assoc, 59 : 911 915, 1959.

3) Brännström, M. and Nyborg, H. : The presense of bacteria in cavities filled with silicate cement and composite resin materials, Swed Dent J, 64:149 155, 1971.

4) Mjör, I.A. : Bacteria in experimentally infected cavity preparations, Scand J Dent Res, 85 : 599 605, 1977.

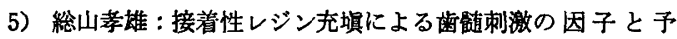
防, the Quintessence, 6:95 108, 1987.

6）井上雅臣 : 象牙啠知営過敏の処置としての亜鉛イオン導入
法, 日歯保誌, $1: 1 \sim 16,1958$.

7) Beech, D.R., Solomon, A. and Bernier, R. : Bond strength of polycarboxylic acid cements to treated dentine, Dent Mater, $1: 154 \sim 157,1985$.

8）清水正弥：4-META/MMA-TBB 系レジンのウシ 象牙貝 への接着一長期安定性と水の影響一，歯材器, $6: 860$ $872,1987$.

9) Manning, M.M. : A new approach to desensitization of cervical dentine, Dent Survey, $37: 731 \sim 734,1961$.

10）津田忠政：イオン導入に関する研究 とくに象牙犋への通 電に伴う最小感知電流および知党過敏症改善勃果につい て, 日㙁保誌, $23: 301 \sim 312,1980$.

11）長谷 徽：象牙質知敩過敏症へのフッ秦イオン尊入法の基 磷的研究, 日歯保誌, $28: 527 \sim 547,1985$.

12）藤正敬夫：イオン導入による象牙犋内金属イオンの漘度分 布についと, 口病誌, 45:74 89, 1978.

13）山賀禮一：お歯黒加ら予防歯科材料人，日歯会報，5：14～ 17. 1979. 